\title{
MACEDONIANS AND ALBANIANS: STEREOTYPES AND ETHNIC DISTANCE
}

\author{
Strashko STOJANOVSKI \\ E-mail: strasko.stojanovski@ugd.edu.mk \\ $\mathrm{PhD}$, Faculty of Law, Goce Delchev University in Shtip \\ Zaneta POPOSKA \\ E-mail: zaneta.poposka@osce.org \\ $\mathrm{PhD}$, OSCE Mission in Skopje
}

\begin{abstract}
The multicultural character of Macedonian society is reflected in the diversity of its ethnic, religious and overall cultural collective entities. Heterogeneous composition is represented on different levels of social interaction and social inclusion. Regional disparities are also characteristic of a specific Macedonian interethnic model. The northwest part of the country is dominated by the second largest ethnic group, the Albanian population, and in the rest of the country, Macedonians are the dominant ethnic group. Also, throughout the country other ethnic groups as Turkish, Roma, Serbian, Vlah and other communities are present. Regarding this composition, different patterns of social interethnic inclusion can be traced, as well as models of building stereotypes and levels of ethnic distance. This paper will use data of research conducted in 2015, comparing similar previous research published in 1997 and 2004.
\end{abstract}

Key words: Ethnic groups, ethnic distance, stereotypes, assimilation, social inclusion.

\section{Introduction}

In the 1990s ethnic and religious conflicts become synonymous for the wider region of the Balkans. Former Yugoslav republics were pushed in violent ethnic clashes and civil wars. ${ }^{1}$ Even newly the independent Republic of

\footnotetext{
${ }^{1}$ By Hammel, Mason \& Stevanović, ethnic diversity of the territory of Yugoslavia was historically one of local mono-ethnicity, expanding to multi-ethnicity in ever larger geographical units. Imperial conquest, refugee flight, and more recently urbanization and the disappearance of small, usually monoethnic, rural settlements over time resulted in greater mixture of the population. The
} 
Macedonia $^{2}$ was excluded in the early stages, in the turn of the new millennia tensions between ethnic Macedonians and Albanians rose, which culminated with the conflict in 2001. ${ }^{3}$ Post conflict period meant that many conflict wounds needed to be healed.

Regarding this, in that period, many researches focused on inter-ethnic interaction in Republic of Macedonia. The interest of scientific community was orientated toward factors of conflict resolution and community integration, though at the same time questions of complexity of inter-ethnic relations also arose. Overall, ethnic tensions were present in the period that followed the conflict and the Ohrid Framework Agreement, many times stimulated by daily political mobilization, arising from nationalism and media manipulation. ${ }^{4}$ This paper attempts to take on comprehensive research of the

most discouraging interpretation of the flow of historical events is that increasing diversity itself led to interethnic antipathy. Also, playing the ethnic card may simply have been a convenient option for politicians seeking broad support, combined with wither world political change after fall of communism and economic disparities of the republics (Hammel, Mason \& Stevanović, 2010). Overall, Yugoslavia is often referred as a country with two alphabets, three religions, four languages, five nations and six federal states called republics (Raskovic and Vuckovski, 2016).

${ }^{2}$ Republic of Macedonia as was a part of former Socialist Federative Republic of Yugoslavia and declare its independence in 1991. In 1993 it become UN member state under the provisional name "the former Yugoslav Republic of Macedonia", due to name dispute conflict with Greece. Since 2019 the country changed its name to Republic of North Macedonia as a result of Prespa Agreement concluded in 2018 in Prespa with Republic of Greece. Even though the national referendum for the name change in Republic of Macedonia was unsuccessful, constitutional changes were passed by national assembly in 2019.

${ }^{3}$ For example, explaining ethnic conflict Horowitz focuses on the difference between dominant and subordinate groups. He finds that so-called economically backward groups are most often the initiators in ethnic conflicts because they perceive that they are inferior to more advanced groups; hence, they seek to catch up in order to boost their own collective self-esteem and be recognised by the more advanced groups. Moreover, backward groups are also fearful that the advanced groups seek to extinguish them, which fuels hostility (Horowitz, 1985).

${ }^{4}$ The Ohrid Agreement that ended the conflict in 2001, provided for a range of legislative and policy measures to improve the position of the Albanians and other minorities by ensuring equality and minority protection. However, many years after the agreement, inter-ethnic relations in Macedonia still remain burdened by prejudice and stereotypes, rather than cooperation and mutual prosperity. Though certain progress has been made, Albanians in Macedonia are still dissatisfied with their position and are claiming more rights at national level (Demjaha, 2017). 
fundamentals for such manifestation of resistance or hostility towards the Other, pointing to factors of development of stereotypes and ethnic distance between individuals of different ethnicities.

This paper includes the research results obtained as part of the project "Impact of Stereotypes and Ethnic Distance on the Phenomena of Discrimination, Hate Speech and Hate Crime." The research was conducted through joint activities of the faculties of law at the University "Goce Delcev" from Shtip, "Iustinianus Primus" from Skopje and the Faculty of Law at the Tetovo State University, and supported by the OSCE Mission to Skopje. The survey was conducted in the course of 2015, based on previously designed methodological framework by the students and teaching staff at the Centre for legal and political research at the Faculty of Law, University "Goce Delcev" in Shtip. Teams of professors and students of the three afore mentioned faculties carried out the research. The processing of data and the respective analysis were undertaken in the course of 2015 and 2016 at the Faculty of law, University "Goce Delcev" in Shtip. The research covered several areas related to certain societal factors, such as gender, age, ethnic and religious background, social status, education, that impact the respondents' perception, inter-ethnic interaction and coexistence or, on the contrary, ethnic distance. Furthermore, it includes various aspects in the analysis of existing stereotypes and their impact on the phenomenon of ethnic distance by use of the Bogardus and Likert scale (Bogardus, 1925; Wark \& Galliher, 2007; Joshi Ankur and others, 2015).

The presentation of the research results also includes the comparison of the results from two researches that use the same or similar methodological framework, in an attempt to present the projections generated from the longitudinal aspect of the methodological approach. The comparison is made with the results from the research "Social Aspects of Ethnic Cohabitation in Republic of Macedonia" conducted by Professor Marija Taseva, PhD from the Institute of sociology at the Faculty of Philosophy in Skopje in 1995, and published in the research paper of Professor Marija Taseva, PhD, "Ethnic Groups in Republic of Macedonia" (contemporary situation)" (Taseva, 1997). The second empirical research was published in 2004 under the title "Albanians and Macedonians: Ethnic Interaction in Republic of Macedonia, Before and After the Conflict from 2001" by Frosina Tasevska (Tasevska, $2004)^{5}$.

The research "Strengthening the Interethnic Communication and Integration in Republic of Macedonia in the Post-conflict Period" was conducted by Frosina Tasevska in 2003, as part of an extensive research for the purposes of the master thesis "Albanians and Macedonians: Ethnic Interaction in Republic of Macedonia, Before and After the Conflict from 2001“, defended in 2004 at the 
There are several other researches conducted on student population (Hristova, Serafimovska, Markovik and Cekik, 2014; Cvetaniva, Atanasov, Markovik, Serafimovska, Cekik, Naumovska, 2016), but due to unified methodology and time distance main comparative approach is with the research of Taseva (1997) and Tasevska (2004).

\section{Stereotypes and Ethnic Distance}

Stereotypes or prejudices are formed by assigning certain features or characteristics to people soley on the basis of their belonging to a certain group. Stereotypes are formed on the grounds of gender, age, ethnic differences, race among others. Stereotypes can be very strong positions, usually established on no realistic basis. Stereotypes and prejudices largely complicate interpersonal communication, and therefore they need to be tackled. Stereotypes may be construed with regard to one's own group, autostereotypes, as well as with regard to other groups, hetero-stereotypes.

Lippmann introduced the term 'stereotype' to refer to the typical picture that comes to mind when thinking about a particular social group (Lippmann, 1922). Cultural stereotypes tend to persevere for both cognitive and social reasons. Cognitively, people often discount stereotype-discrepant behaviors, attributing them to situational factors, while making dispositional (and stereotype-reinforcing) attributions for stereotype-consistent behaviors (Hewstone, 1990). While Rinehart (Rinehart, 1963) emphasized the learned and interaction-based nature of stereotype formation, stereotypes can also have deeper historical and political roots, and are popularized by literature ${ }^{6}$ and the media (Várnai, 2009). Furthermore, politics often goes hand in hand with the building of stereotypes, especially in the case of Balkan countries (Burdiak, 2010). ${ }^{7}$

Institute of sociology, Faculty of Philosophy in Skopje, under the mentorship of professor Marija Taseva, PhD (Tasevska, 2004).

${ }^{6}$ For example Martinoska is using analyses on Macedonian folklore, where the positive image and the epic glorification of the Macedonian heroes are opposed to the manifested negative judgments about Others (mostly Turks and Arabs), often based upon ethnic stereotypes (Martinoska, 2005).

${ }^{7}$ Ethnic stereotypes cannot appear out of nothing, they have direct connection with the historical reality. In the history of Balkan politics appeared Serbs, Greeks, Bulgarians, Romanians, Montenegrins, Slovenes, Albanians, Turks, Muslims (Bosnia) and Macedonians. Stereotypes are in those cases often put in negation of the political reality of the Other very existence, with main goal to bust its own national agenda and used in daily political mobilization (Burdiak, 2010). On other hand many stereotypes on the Balkans are stimulated by long 
Recent definitions of prejudice bridge the individual-level emphasis of psychology and the group-level focus of sociology by concentrating on the dynamic nature of prejudice. Eagly and Diekman, for example, view prejudice as a mechanism that maintains status and role differences between groups. But, they also emphasize how individuals' reactions contribute to this process. People who deviate from their group's traditional role arouse negative reactions; others who exhibit behaviors that reinforce the status quo elicit positive responses (Eagly, A. H., \& Diekman, A. B., 2005).

Prejudices are formed as opposites of affective stereotypes. Prejudice is an act of refusal and hostility towards a person in a group due to inflexible and faulty generalizations regarding that group. Prejudices are simple but generic opinions full of negative emotions and resistant or almost impossible to change through experiences. The concept of prejudice is essentially determined by normative and moral contents and differs from other attitudes by social undesirability (Ültanır Gürcan, Emel Ültanır and Ayşe Irkörücü, 2016).

A ethnic group is a group of people sharing one common distinctive culture, and a societal group that shares the same ideology, institutions as well as customs and feeling of homogeneity. An ethnic group has one common cultural tradition and feeling of identity and exists as subgroup within the larger society. Ethnic identity or ethnicity is the basic instance of the collective identification which is based on the perceived cultural differences. Ethnicity is indeed related to the culture and it is a product of social interaction. Hence, it can be both collective and individual both regarding the social interaction and self-identification.

Ethnic distance is a collective feeling of closeness, i.e., distance in relation to other groups, which is based on certain objective criteria, which in this particular case arises from the feeling of belonging to certain ethnic community. ${ }^{8}$ Ethnic distance is a product of stereotypes and subjective perception; hence, it often offers a distorted image of the Other. The concept of social distance emerged from sociometry and was first developed in the mid-1920s by Park (Park, 1924) as a cumulative ordinal-type psychological scale focusing on a person's willingness to engage in various levels of social

historical perception of the West for this region and its people (Zupancic and Arbeiter, 2017).

${ }^{8}$ By Karakayali, most groups have social distance norms that differentiate "us" from "them." Contrary to a widespread assumption in the sociological literature, however, these normative distinctions, even when they are collectively recognized, do not always overlap with the affective orientations of group members in a uniform manner. Relations between normatively close members of a group are not always warm and friendly, and normatively distant groups can sometimes be an object of reverence and love (Karakayali, 2009). 
relationships in racial and religiously diverse groups. It later connected with Bogardus" prejudice research. As a result of one of the earliest longitudinal attitudinal studies examining "diversity and difference" (Wark \& Galliher, 2007).

According to Caselli, Francesco and Coleman, ethnic distance is the cost to be borne by a member of one group to successfully pass himself as a member of the other group. In general, we would expect ethnic distance to be maximal when there are differences in skin color and other physical characteristics that make passing all but impossible. Distance may be fairly high in the case of religious differences among groups. Language barriers could plausibly be argued to be a somewhat weaker source of distance. Potential infiltrators can assimilate through learning the language, or more realistically through having one's children do so. Finally, ethnic cleavages that are only marked by a shared sense of identity or history, unsupported by additional differences of color, religion, language, or other observable characteristics, should be associated with the lowest levels of ethnic distance (Caselli and Coleman, 2013). Social distance is equally determined ma several of factors as education ${ }^{10}$, social status, origin and segregation factors ${ }^{11}$, ethnicity, culture,

${ }^{9}$ The concept of social distance has been designed by Emory Bogardus and has been around since the 1920s as a simple yet effective research tool for studying intergroup/interpersonal relationships and the degrees of understanding/acceptance and intimacy that characterize (pre)social relationships. By offering explanations of distance toward other/outer groups, Bogardus points out that they are mostly associated with fear. The most common causes of distance are traditional beliefs and acceptance of public opinion, unpleasant personal experiences from childhood and unpleasant experiences into adulthood. In addition, Bogardus points out that individuals often incorrectly generalize the activities of several members of the group that they have personally encountered to the whole group (Bogardus 1925).

10 For example, regarding minority groups, according to Nederlands, Verberk, Scheepers and Felling raise questions about the important effects of education and perceived ethnic threat (Verberk, Scheepers and Felling, 2002).

11 There are complex relations between ethnic residential segregation, inter-ethnic contacts and attitudes toward ethnic minorities, especially the extent to which contact mediates the relations between ethnic composition of neighbourhood and attitudes toward ethnic minorities. Regarding European societies, residential segregation has significant consequences for differential opportunities for quality of life and for standard of living including opportunities for attainment of quality education, exposure to crime, differential access to social services, medical facilities, and cultural amenities (Semyonov and Glikman, 2009). 
or language, ${ }^{12}$ and in recent years, related with various research, focused on immigration questions (Ebner and Helbling, 2016).

Ethnic conflict ${ }^{13}$ is a conflict among two or several different ethnic groups, where the ethnic and cultural differences come to the fore. Minority groups which settled a certain territory, where they feel like a majority and experience the territory as traditionally and historically belonging to them, most often take part in ethnic conflicts.

\section{Research Methodology}

The research "Impact of Stereotypes and Ethnic Distance on the Phenomena of Discrimination, Hate Speech and Hate Crime" was conducted in 2015, included 519 respondents, high school and university students from all regions of the country. According to the ethnic origin, most of the respondents are from the Macedonian and Albanian ethnic community. Three hundred forty two respondents or $65.9 \%$ were Macedonians, while 156 respondents or $30.1 \%$ were Albanians. 209 respondents, or $40.3 \%$ were secondary school students, (83 were from the secondary schools in Skopje, 56 respondents were from the secondary schools in Tetovo and Gostivar, and 71 respondents were from the secondary schools in Strumica, Stip and Vinica ). Another 307 respondents, or $59.2 \%$ were university students, (117 students at the University "Goce Delcev"in Stip, 64 respondents were students at the University "Ss Cyril and Methodious" in Skopje, and 125 respondents were

${ }^{12}$ In the context of the region of South-Eastern Europe, including Macedonian social context, religion has also strong influence in building social distance between groups. The regional example refers that religion is often mixed with ethnicity and culture (Malenica, Kova and Kardum, 2019). Pace lists five basic principles of identity politics (Pace 2009):

1. Political identities are social, but also political movements.

2. Identity becomes something that is unquestionable, sacred and unchangeable.

3. Identity serves to strengthen social activity.

4. Religion, using rituals and symbols, indirectly generates the space within which (national)

identities are perceived to be endangered by the enemies.

5. That in the efforts to preserve the endangered identity conflicts with the enemy represent the battle of the Good against the Force (Pace, 2009).

${ }^{13}$ Some recent research shows that ethnic divisions matter for conflict and public goods when they are associated with cultural differences across ethnic groups. Therefore, ethnic divisions matter for conflict, if they only overlap with cultural cleavages (Desmet, Ortuco-Orthn, and Wacziarg, 2017). 
students at the Tetovo State University). The locations choice is in educational institutions (high schools and University in Eastern part of Macedonia with dominant ethnic Macedonian population, Northwestern part with predominant ethnic Albanian population and Skopje, as a capital city and with ethnic mixed population.

Due to usage of comparative method with previously made researches mentioned in the introduction, from the research of prof. Tasheva in 1995 (Taseva, 1997) are used selected data from age 18 to 27 , and research of Tasevska in 2003 (Tasevska, 2004) was conducted on student population on several Faculties on University "Ss. Cyril's and Methodius" in Skopje.

\section{Results of the Research}

\section{Ethnic and religious background and interethnic marriages}

Most of the respondents, $66.5 \%$ (59.8\% of Orthodox respondents and $86.6 \%$ of Muslim respondents), think that it is better to enter into marriage with a man or women of the same religion. The lower the religiosity of the respondents, the higher the percentage of respondents who are undecided or prefer marriage with a man or woman who is not religious. However, even the less religious respondents do not prefer the other religious background. The higher the religiosity, the more conservative are the attitudes regarding a marriage with members of other ethnic communities. Among the respondents who are not religious, $36.4 \%$ prefer marriage with man or woman of the same religion, while among the respondents who are slightly religious, such marriage is preferred by $59.1 \%$ of the respondents; $70.6 \%$ of religious respondents prefer marriage with a man or woman of the same religion, while $77,1 \%$ of very religious respondents prefer marriage with a man/woman of the same religion (Chart 1). Respondents have similar attitudes with regard to a marriage with a man or woman of the same ethnic origin. Almost $61.1 \%$ (Chart 2). $53.5 \%$ of the Macedonian respondents think it is better to marry a man or woman of the same ethnic origin, while this percentage is significantly higher regarding the same attitude among the Albanian respondents, at $82.1 \%$ (Chart 3). It is an indication that ethnic distance is more prevalant among the Albanian respondents when it comes to the possibility to enter into a marriage with ethnic non-homogenous groups.

Similarly, on the question of what is the ethnic / religious origin of your three best friends?, the answers are almost identical. Among the members of the Albanian ethnic community and Muslim religion, the three best friends are Albanians or Muslim, while among the respondents from the Macedonian ethnic community and Christian religion, their best friends are predominantly Macedonians and Christian. 


\section{Chart 1}

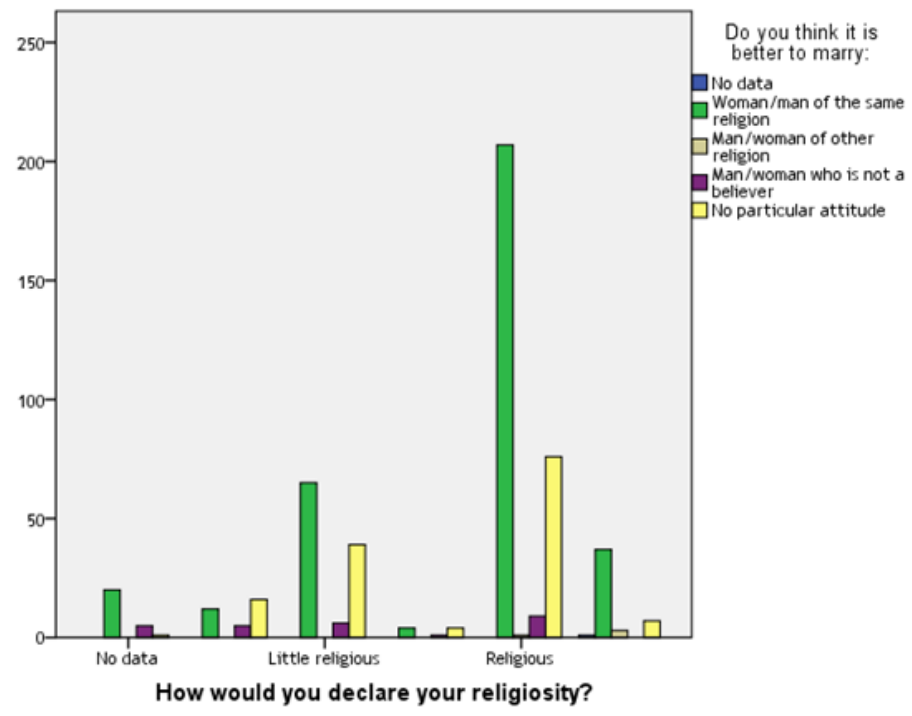

Chart 2

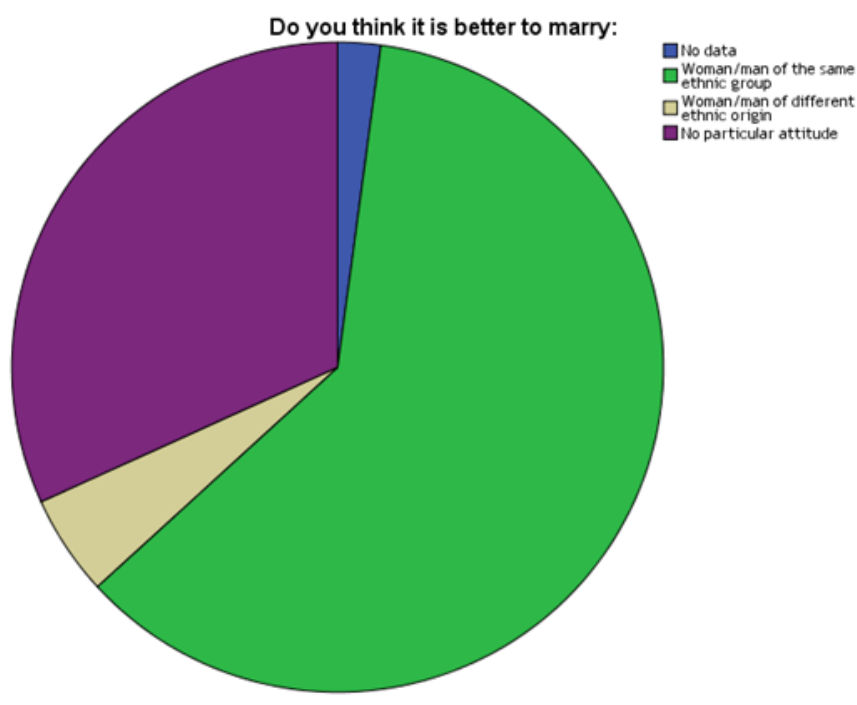




\section{Chart 3}

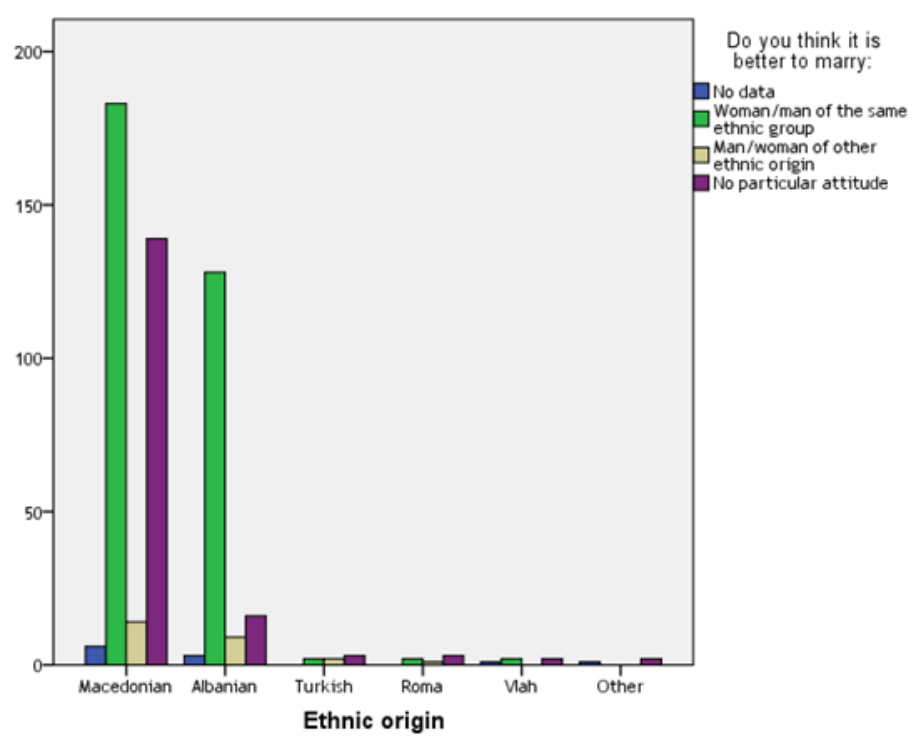

\section{Impact of stereotypes on the ethnic distance}

This part of the research examines the characteristic traits of certain ethnic communities. Different traits were offered randomly for each ethnic community. The respondents were given the following task: to read all the stated traits (attributes) and to enter assign a number to five to ten traits which are typical or characteristic for the respective ethnic community. Typical traits of an ethnic community are traits that most people (members) of that ethnic group have in common.

Given the small number of respondents from the small ethnic groups, the presentation of results includes only the stereotypes that respondents from the Macedonian and Albanian ethnic groups stated for the other ethnic groups. Macedonian respondents have positive stereotypes about themselves, such as courageous, proud, hardworking, hospitable and joyful. At the same time, this group construes stereotypes or assumed characteristics regarding the other ethnic groups. Within the five top stereotypes about the Albanian community, there are positive characteristics, such as courageous and united; however, the negative characteristics, such as uncultured, hard-hearted and love to rule, prevail. Respondents of Albanian ethnic origin construe positive attributes for themselves, such as courageous, proud, goodhearted, hospitable and feisty, while they have negative stereotypes for the Macedonian community, such as hard-hearted, do not like other nations, selfish, love to rule and envious. Both the respondents from the Macedonian and Albanian ethnic groups have 
positive stereotypes for the Turkish ethnic community, and negative stereotypes for the Roma ethnic community. In addition, Macedonian respondents have positive stereotypes for the Serbian ethnic group, while Albanian respondents have negative stereotypes for this ethnic group.

The comparison of the results about the stereotypes that both Macedonians and Albanians construe about themselves (auto-stereotypes) and for the others (hetero-stereotyps), shows the situation, as presented in Table 1 and Table 2. The characteristics presented in the respective tables may be divided in three groups: 1. Heroic-libertarian (courageous, feisty, proud, like to rule), 2. Cultural (progressive, outmoded, hardworking, lazy, dirty, polite) and 3. Interactional (hospitable, joyful, selfish). These groups may be supplemented with the Osgood's semantic differential, which considers the stereotypes from the aspect of evaluation (good-bad), potency (strong-weak) and activity (active-passive) (Tashevska, 2004). If one considers the stereotypes that Macedonians construe about themselves, all groups of stereotypes can be noticed; however, although the cultural concepts prevailed in the past, currently one can notice a shift towards the heroic-libertarian concept. With regard to the hetero-stereotypes about the Albanian ethnic community, the cultural level of stereotypes prevails as well as the heroic-libertarian stereotypes from the research conducted in 1995 and 2003. Regarding the latter, one can notice a significant shift in 2015. The first most important stereotype about the Albanian ethnic group is that with heroic-libertarian meaning. Among the auto-stereotypes of the Albanians, the positive heroiclibertarian stereotypes prevail, as well as the cultured; however, there are negative heroic-libertarian stereotypes about the Macedonian community as well as negative cultural and interactional stereotypes. Despite the mild shift in 2015, if compared to the two previous studies, one can conclude that the competitiveness and parallelism still exist regarding the construing of stereotypes among the two biggest communities in the country, which, in fact, is an indicator of insufficiently developed communication among the individuals from both communities which, in turn, further creates preconditions for segregation in the society. Furthermore, the prejudices of these two groups have strongly highlighted paternalistic characteristics and competitiveness component. The first one refers to behavior with distinct negative drive when it comes to the valuable characteristics and cultural level of the Other, while the second one indicates the competitive relations among the ethnic groups, which is incited by the feeling of being threatened and having limited access to the social resources. ${ }^{14}$

${ }^{14}$ By the research results of Atanasov and Naumovska dominant auto stereotypes of Macedonians are hardworking, peaceful and goodhearted, and dominant hetero stereotypes toward Albanian are aggressive and enemies. Dominant auto stereotypes of Albanians are brave and hardworking and hetero stereotypes 


\section{Table 1}

\begin{tabular}{|l|l|l|l|l|l|l|}
\hline \multicolumn{7}{|c|}{ MACEDONIANS } \\
\hline $\begin{array}{c}\text { Ty } \\
\text { pe } \\
\text { of } \\
\text { im } \\
\text { age }\end{array}$ & $\begin{array}{c}\text { Macedon } \\
\text { ians for } \\
\text { themselv } \\
\text { es } \\
\text { (autoster } \\
\text { eotype) }\end{array}$ & $\begin{array}{c}\text { Macedoni } \\
\text { ans for } \\
\text { Albanians } \\
\text { (heteroste } \\
\text { reotype) }\end{array}$ & $\begin{array}{c}\text { Macedoni } \\
\text { ans for } \\
\text { fhemselve } \\
\text { s } \\
\text { (autostere } \\
\text { otypes) }\end{array}$ & $\begin{array}{c}\text { Macedoni } \\
\text { ans for } \\
\text { Albanians } \\
\text { (heteroste } \\
\text { reotype) }\end{array}$ & $\begin{array}{c}\text { Macedoni } \\
\text { ans for } \\
\text { themselve } \\
\text { s } \\
\text { autostere } \\
\text { otypes) }\end{array}$ & $\begin{array}{c}\text { Macedoni } \\
\text { ans for } \\
\text { Albanians } \\
\text { (heteroste } \\
\text { reotype) }\end{array}$ \\
\hline $\begin{array}{l}\text { Tra } \\
\text { it 1 }\end{array}$ & Proud & Outmoded & Good & Aggressive & $\begin{array}{l}\text { Courageo } \\
\text { us }\end{array}$ & $\begin{array}{l}\text { Courageou } \\
\text { songen }\end{array}$ \\
\hline $\begin{array}{l}\text { Tra } \\
\text { it 2 }\end{array}$ & $\begin{array}{l}\text { Hospitabl } \\
\text { e }\end{array}$ & Uncultured & Lenient & Uncultured & Proud & Uncultured \\
\hline $\begin{array}{l}\text { Tra } \\
\text { it 3 }\end{array}$ & $\begin{array}{l}\text { Courageo } \\
\text { us }\end{array}$ & $\begin{array}{l}\text { Hard- } \\
\text { hearted }\end{array}$ & Passive & $\begin{array}{l}\text { Hard- } \\
\text { hearted }\end{array}$ & $\begin{array}{l}\text { Hardworki } \\
\text { ng }\end{array}$ & United \\
\hline $\begin{array}{l}\text { Tra } \\
\text { it 4 }\end{array}$ & $\begin{array}{l}\text { Hardwork } \\
\text { ing }\end{array}$ & $\begin{array}{l}\text { Do not like } \\
\text { other } \\
\text { nations }\end{array}$ & Lenient & $\begin{array}{l}\text { Like to } \\
\text { rule }\end{array}$ & Hospitable & $\begin{array}{l}\text { Hard- } \\
\text { hearted }\end{array}$ \\
\hline $\begin{array}{l}\text { Tra } \\
\text { it 5 }\end{array}$ & $\begin{array}{l}\text { Goodhear } \\
\text { ted }\end{array}$ & Smugglers & $\begin{array}{l}\text { Goodheart } \\
\text { ed }\end{array}$ & Smugglers & Joyful & $\begin{array}{l}\text { Like to } \\
\text { rule }\end{array}$ \\
\hline
\end{tabular}

\section{Table 2}

\begin{tabular}{|l|l|l|l|l|l|l|}
\hline $\begin{array}{l}\text { Ty } \\
\text { pe } \\
\text { of } \\
\text { im } \\
\text { age }\end{array}$ & $\begin{array}{c}\text { Albanian } \\
\text { s for } \\
\text { themselv } \\
\text { es } \\
\text { (autoster } \\
\text { eotype) }\end{array}$ & $\begin{array}{c}\text { Albanians } \\
\text { for } \\
\text { Macedoni } \\
\text { ans } \\
\text { (heteroster } \\
\text { eotype) }\end{array}$ & $\begin{array}{c}\text { Albanian } \\
\text { s for } \\
\text { themselv } \\
\text { es } \\
\text { (autoster } \\
\text { eotype) }\end{array}$ & $\begin{array}{c}\text { Albanians } \\
\text { for } \\
\text { Macedoni } \\
\text { ans } \\
\text { (heteroster } \\
\text { eotype) }\end{array}$ & $\begin{array}{l}\text { Albanian } \\
\text { s for } \\
\text { themselv } \\
\text { es } \\
\text { (autoster } \\
\text { eotype) }\end{array}$ & $\begin{array}{c}\text { Albanians } \\
\text { for } \\
\text { Macedoni } \\
\text { ans } \\
\text { (heteroster } \\
\text { eotype) }\end{array}$ \\
\hline $\begin{array}{l}\text { Tra } \\
\text { it 1 }\end{array}$ & $\begin{array}{l}\text { Courageo } \\
\text { us }\end{array}$ & $\begin{array}{l}\text { Do not like } \\
\text { other } \\
\text { nations }\end{array}$ & $\begin{array}{l}\text { Courageo } \\
\text { us }\end{array}$ & $\begin{array}{l}\text { Do not like } \\
\text { other } \\
\text { nations }\end{array}$ & $\begin{array}{l}\text { Courageo } \\
\text { us }\end{array}$ & $\begin{array}{l}\text { Hard- } \\
\text { hearted }\end{array}$ \\
\hline $\begin{array}{l}\text { Tra } \\
\text { it 2 }\end{array}$ & Proud & Selfish & Feisty & Selfish & Proud & $\begin{array}{l}\text { Do not like } \\
\text { other } \\
\text { nations }\end{array}$ \\
\hline $\begin{array}{l}\text { Tra } \\
\text { it 3 }\end{array}$ & $\begin{array}{l}\text { Hospitabl } \\
\text { e }\end{array}$ & $\begin{array}{l}\text { Hard- } \\
\text { hearted }\end{array}$ & Proud & Passive & $\begin{array}{l}\text { Goodhear } \\
\text { ted }\end{array}$ & Selfish \\
\hline $\begin{array}{l}\text { Tra } \\
\text { it 4 }\end{array}$ & $\begin{array}{l}\text { Hardwork } \\
\text { ing }\end{array}$ & Cowards & $\begin{array}{l}\text { Hardwork } \\
\text { ing }\end{array}$ & Cowards & $\begin{array}{l}\text { Hospitabl } \\
\text { e }\end{array}$ & $\begin{array}{l}\text { Love to } \\
\text { rule }\end{array}$ \\
\hline $\begin{array}{l}\text { Tra } \\
\text { it 5 }\end{array}$ & $\begin{array}{l}\text { Goodhear } \\
\text { ted }\end{array}$ & Lazy & United & Bad & Feisty & Envious \\
\hline
\end{tabular}

toward Macedonians are scared, bad and enemies (Atanasov and Naumovska, 2016). 
The scale of interpersonal ethnic preference is used in order to present the subjective dimension of interaction, the feeling of attachment and distance among the members of ethnic groups in Republic of Macedonia. Table 3 shows the results obtained from the question concerning respondents ordering of the ethnic groups based on the closeness they feel to each of the groups. The attachment coefficient level is determined in the numerical range of 1-5, where 1 is the greatest distance and 5 the greatest attachment. The results are then presented from the aspect of comparison with the results from the research undertaken in 1995, 2003 and 2015. Presented data show that the ethnic distance coefficient, among the Macedonian and Albanian ethnic community, was greatest in the post-conflict period in 2003. Given the results, one can notice that the ethnic distance is closely related to the confession of the groups, with minor exception for the Turkish community where the constant is most stable both among the Macedonian and Albanian respondents. Also, the ethnic distance in the perception of the Albanian respondents is smaller compared to the Macedonian ethnic group, while the distance that Macedonian respondents maintain from the Albanian ethnic group is somewhat larger. An exception to this conclusion is presented by the research results from 2003. It is both encouraging and worth noting that despite the narrow scope, the ethnic distance from the last 2015 research is lowest compared to previously conducted research. In particular, this is shown in the attitude of the Macedonian ethnic group towards the Albanian ethnic group, where from the maximal distance in 2003 and 1.07 index, there is an enhanced feeling of closeness in 2015, with a 3.18 index. Although the respective index is lower in the perception of the Albanian ethnic community regarding the closeness with the Macedonian ethnic community, there is a positive shift from 1.12 in 1995 and maximum possible distance of 1 in 2003, and up to 1.98 in 2015. Overall, from the last research in 2015, in the perception of both Macedonian and Albanian respondents, one can notice a downward trend for the ethnic distance in interpersonal relations, as well as in the attitudes the respondents have towards the other ethnic groups. The only exception is the ethnic distance that Macedonians maintain from the Serbian ethnic group, which had the lowest margin in the previous researches, especially in 2003 when it accounted for 4.78. Nevertheless, the latest research shows a clear upward trend regarding this distance, and accounts for 3.68 in 2015. Despite the considerable existing ethnic distance among the two biggest ethnic communities in Republic of Macedonia, the results are indicative of a gradual improvement of interethnic relations in the country, a clear tendency for decline in such ethnic distance (Chart 4 and Chart 5). 
Table 3

\begin{tabular}{|l|c|c|c|c|c|c|}
\hline \multirow{2}{*}{} & \multicolumn{6}{|c|}{ Ethnic origin } \\
\cline { 2 - 7 } & \multicolumn{3}{|c|}{ Macedonian } & \multicolumn{3}{c|}{ Albanian } \\
\cline { 2 - 7 } & $\mathbf{1 9 9 5}$ & $\mathbf{2 0 0 3}$ & $\mathbf{2 0 1 5}$ & $\mathbf{1 9 9 5}$ & $\mathbf{2 0 0 3}$ & $\mathbf{2 0 1 5}$ \\
\hline MACEDONIANS & 4.87 & 4.92 & 4.73 & 2.24 & 1.07 & 3.18 \\
\hline ALBANIANS & 1.12 & 1 & 1.98 & 4.88 & 5.00 & 4.92 \\
\hline TURKS & 2.34 & 2.30 & 2.70 & 3,67 & 3.70 & 3.51 \\
\hline ROMA & 1.54 & 1.23 & 2.02 & 1.35 & 1.30 & 2.06 \\
\hline SERBS & 4.34 & 4.78 & 3,68 & 1.02 & 1 & 1.44 \\
\hline
\end{tabular}

Chart 4

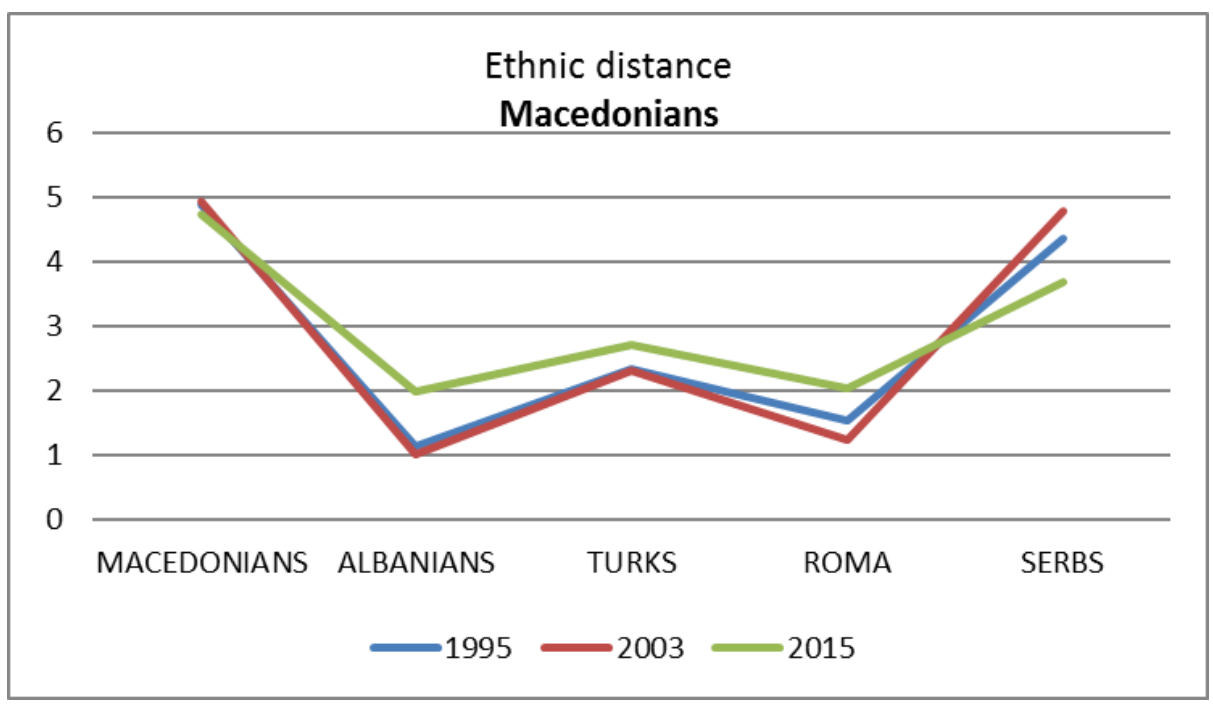

Chart 5

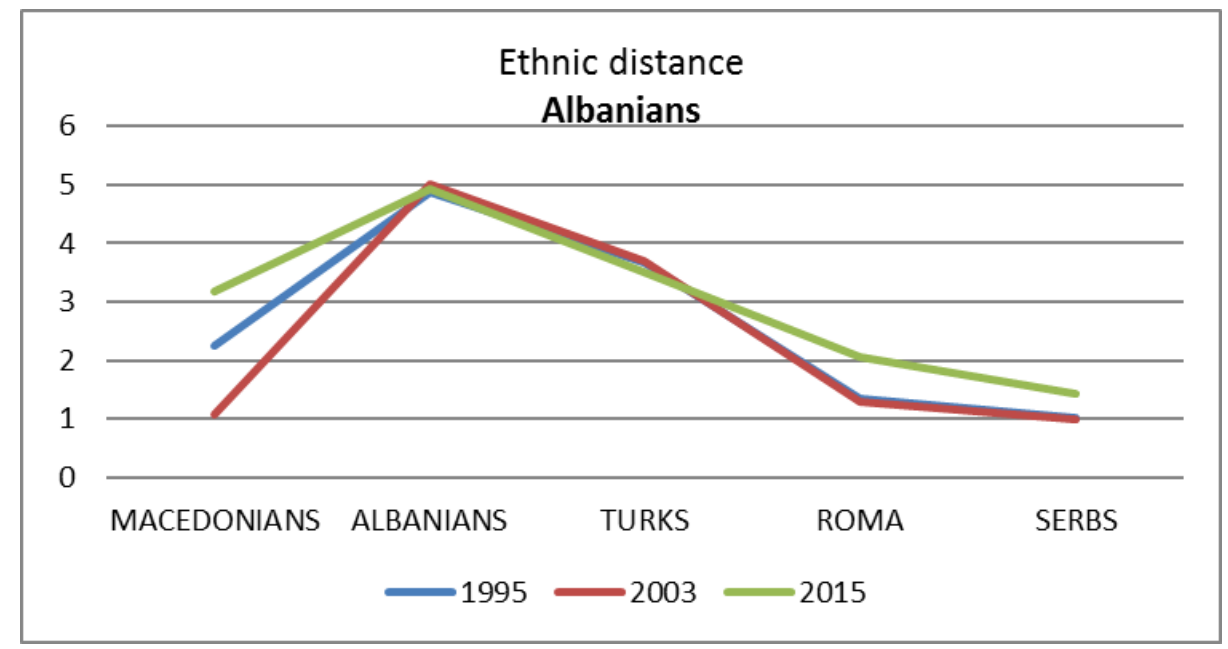


Members of different ethnic communities and different confessions live together in the country. This part of the research aims to examine which are the relations that the respondents would like to have with an ordinary, neither best nor worse, member of certain ethnic community and confession. Tables 4, 5, 6 and 7, below, present the attitudes of the respondents from the empirical research of 2015. The questions refer to the interpersonal ethnic and religious distance (Attitudes "To mingle with him/her and be my friend" and "My sister/brother or relative to get married to him/her"), the ethnic and religious distance connected with the place of residence ("To live with me in the same municipality" and "To live with me at the same place"), ethnic distance related to the social position ("To be mayor in my municipality", "To represent the municipality in the Parliament" and "To be director of the organization which employs me"), as well as educational distance ("His children to attend the same school as my children"). Also, some of the attitudes refer to the use of the Bogardus ethnic distance scale.

With regard to the interpersonal distance, one can notice somewhat narrower distance of the Macedonian ethnic community from the others in comparison with the attitudes of the respondents from the Albanian ethnic community. It is interesting to note that, despite the minimal difference, the religious barrier in the interpersonal relations among the ethnic communities is not always overriding. For instance, the ethnic distance among the respondents of the Macedonian ethnic group towards the Turkish community is lower than the interpersonal distance, which, on the other hand, is manifested by the respondents of the Albanian ethnic community. The correlational interpersonal relations are also similar in the perception of the respondents from the two largest religious communities (Christian-Orthodox and Muslim), whereas the interpersonal distance of the respondents from the ChristianOrthodox community towards the others is smaller when compared to the distance maintained by the respondents of Islam religion.

Speaking of the ethnic distance in connection with the place of residence, one can notice similar attitudes among the two dominant ethnic communities in the country, with the exception that the distance of the Albanian ethnic community from the Roma and Serbian ethnic community is considerably larger. With regard to religion, one can notice considerable distance by the members of the Islamic community when compared to the other confessions, and when compared to the attitudes that respondents of Christian-Orthodox confession have towards the others. The situation is similar concerning the ethnic and religious distance in respect of the social position and educational distance.

The data presented in Table 4 to 7 , show that the largest margin of ethnic distance among the responding Macedonians refers to the interpersonal distance from the Roma ethnic community, i.e. the greatest distance is in terms of the attitude "My sister or relative to get married to him", where the 
preference for the Roma ethnic community accounts for only $8.2 \%$. Furthermore, there is a distinct ethnocentrism among the Albanian respondents, and the same can be noticed in the distinct ethnic distance from the Roma and Serbian ethnic community on all grounds; though the ethnic distance also exists on the interpersonal level, and there is distinct ethnic distance concerning the place of residence, social position as well as educational distance. The interpersonal ethnic distance is most prevailing with respect to the Roma ethnic community, where only 1.9 of the Albanian respondents opted for the statement "My sister or relative to get married to him". The reasons for such attitude towards the Roma community, despite the confessional closeness, can be identified with the very distinct traditional stigmatization of the Roma community. On the other hand, the Serbian community is experienced as the greatest ethnic rival, hence, also as a threat to the Albanian community. With regard to the Macedonian ethnic community, the attitudes of the Albanian respondents show the greatest interpersonal ethnic distance. For instance, $12 \%$ of the Macedonians would agree to their sister or relative marrying an Albanian, while only $3.8 \%$ of the Albanians gave this answer on the same question. In spite of that, one can notice that for the second statement that refers to the interpersonal distance "To mingle with him/her and be my friend", the ethnic distance is smallest in the correlational relations of Macedonians, Albanians and Turks. In addition, the educational distance is also smaller among the aforementioned groups. ${ }^{15}$

With regard to the religious distance, the respondents of the ChristianOrthodox and the Islamic religion show distance from the Protestants. Religious distance among the Christians-Orthodox and respondents of the Islamic religion is on the ground of interpersonal religious distance, that is, regarding the statement "My sister or relative to marry him", which is acceptable only for $7 \%$ of the Muslim respondents, and for $19 \%$ of the Orthodox respondents. (Table 6 and 7).

${ }^{15}$ Similar results can be noticed in the research of Atanasov and Naumovska, where the greatest distance of ethnic Macedonian students is toward ethnic Albanians and Roma and closest toward Serbs, and of Albanian students the ethnic distance is strongest toward Serbs Vlahs and Roma, and closest toward the Turks (Atanasov and Naumovska, 2016). 


\section{Table 4}

\section{MACEDONIANS}

\begin{tabular}{|l|c|c|c|c|c|}
\hline & MACEDONIAN & ALBANIAN & TURK & ROMA & SERB \\
\hline $\begin{array}{l}\text { To live with me } \\
\text { in the same } \\
\text { municipality }\end{array}$ & $89.8 \%$ & $31.3 \%$ & $39.8 \%$ & $34.6 \%$ & $58.5 \%$ \\
\hline $\begin{array}{l}\text { To live with me } \\
\text { at the same } \\
\text { place }\end{array}$ & $86 \%$ & $24.9 \%$ & $34.2 \%$ & $19.3 \%$ & $54.1 \%$ \\
\hline $\begin{array}{l}\text { His children to } \\
\text { attend the same } \\
\text { school as my } \\
\text { children }\end{array}$ & $84.8 \%$ & $31.3 \%$ & $43 \%$ & $29.2 \%$ & $57.9 \%$ \\
\hline $\begin{array}{l}\text { To mingle with } \\
\text { him/her and be } \\
\text { my friend }\end{array}$ & $84.8 \%$ & $35.4 \%$ & $50 \%$ & $28.7 \%$ & $65.2 \%$ \\
\hline $\begin{array}{l}\text { My sister or } \\
\text { relative to get } \\
\text { married to him }\end{array}$ & $86.3 \%$ & $12 \%$ & $16.4 \%$ & $8.2 \%$ & $41.5 \%$ \\
\hline $\begin{array}{l}\text { To be mayor of } \\
\text { my municipality }\end{array}$ & $90.1 \%$ & $15.2 \%$ & $15.8 \%$ & $10.8 \%$ & $24 \%$ \\
\hline $\begin{array}{l}\text { To be director } \\
\text { of the } \\
\text { organization } \\
\text { where I am } \\
\text { employed }\end{array}$ & $89.2 \%$ & $21.3 \%$ & $27.2 \%$ & $15.8 \%$ & $35.4 \%$ \\
\hline $\begin{array}{l}\text { To represent my } \\
\text { municipality in } \\
\text { the Parliament }\end{array}$ & $89.5 \%$ & $16.1 \%$ & $18.4 \%$ & $11.1 \%$ & $26.6 \%$ \\
\hline
\end{tabular}




\section{Table 5}

\section{ALBANIANS}

\begin{tabular}{|l|c|c|c|c|c|}
\hline & MACEDONIAN & ALBANIAN & TURK & ROMA & SERB \\
\hline $\begin{array}{l}\text { To live with me } \\
\text { in the same } \\
\text { municipality }\end{array}$ & $23.1 \%$ & $84 \%$ & $37.8 \%$ & $7.7 \%$ & $7.7 \%$ \\
\hline $\begin{array}{l}\text { To live with me } \\
\text { at the same } \\
\text { place }\end{array}$ & $15.4 \%$ & $88.5 \%$ & $32.1 \%$ & $5.8 \%$ & $4.5 \%$ \\
\hline $\begin{array}{l}\text { His children to } \\
\text { attend the same } \\
\text { school as my } \\
\text { children }\end{array}$ & $20.5 \%$ & $84.6 \%$ & $30.1 \%$ & $5.1 \%$ & $6.4 \%$ \\
\hline $\begin{array}{l}\text { To mingle with } \\
\text { him/her and be } \\
\text { my friend }\end{array}$ & $27.6 \%$ & $80.8 \%$ & $37.8 \%$ & $5.8 \%$ & $5.8 \%$ \\
\hline $\begin{array}{l}\text { My sister or } \\
\text { relative to get } \\
\text { married to him }\end{array}$ & $3.8 \%$ & $91 \%$ & $14.1 \%$ & $1.9 \%$ & $2.6 \%$ \\
\hline $\begin{array}{l}\text { To be mayor of } \\
\text { my } \\
\text { municipality }\end{array}$ & $11.5 \%$ & $87.2 \%$ & $15.4 \%$ & $6.4 \%$ & $5.1 \%$ \\
\hline $\begin{array}{l}\text { To be director } \\
\text { of the } \\
\text { organization } \\
\text { where I am } \\
\text { employed }\end{array}$ & $17.3 \%$ & $86.5 \%$ & $18.6 \%$ & $6.4 \%$ & $8.3 \%$ \\
\hline $\begin{array}{l}\text { To represent my } \\
\text { municipality in } \\
\text { the Parliament }\end{array}$ & $17.3 \%$ & $86.5 \%$ & $16 \%$ & $5.8 \%$ & $7.1 \%$ \\
\hline
\end{tabular}




\section{Table 6}

\section{CHRISTIAN ORTHODOX RELIGION}

\begin{tabular}{|l|c|c|c|c|}
\hline & ORTHODOX & MUSLIM & CATHOLIC & PROTESTANT \\
\hline $\begin{array}{l}\text { To live with me in } \\
\text { the same } \\
\text { municipality }\end{array}$ & $89.5 \%$ & $46.7 \%$ & $50.2 \%$ & $32.5 \%$ \\
\hline $\begin{array}{l}\text { To live with me at } \\
\text { the same place }\end{array}$ & $90.1 \%$ & $38.4 \%$ & $44 \%$ & $27.9 \%$ \\
\hline $\begin{array}{l}\text { His children to } \\
\text { attend the same } \\
\text { school as my } \\
\text { children }\end{array}$ & $87 \%$ & $43.7 \%$ & $46.4 \%$ & $31 \%$ \\
\hline $\begin{array}{l}\text { To mingle with } \\
\text { him/her and be } \\
\text { my friend }\end{array}$ & $89.5 \%$ & $43.3 \%$ & $47.7 \%$ & $30.3 \%$ \\
\hline $\begin{array}{l}\text { My sister or } \\
\text { relative to get } \\
\text { married to him }\end{array}$ & $90.4 \%$ & $19.8 \%$ & $26.9 \%$ & $17 \%$ \\
\hline $\begin{array}{l}\text { To be mayor of } \\
\text { my municipality }\end{array}$ & $90.1 \%$ & $25.4 \%$ & $31 \%$ & $21.1 \%$ \\
\hline $\begin{array}{l}\text { To be director of } \\
\text { the organization } \\
\text { where I am } \\
\text { employed }\end{array}$ & $90.4 \%$ & $28.5 \%$ & $30.3 \%$ & $21.7 \%$ \\
\hline $\begin{array}{l}\text { To represent my } \\
\text { municipality in } \\
\text { the Parliament }\end{array}$ & $85.8 \%$ & $25.1 \%$ & $29.4 \%$ & $18.9 \%$ \\
\hline
\end{tabular}




\section{Table 7}

\section{MUSLIM RELIGION}

\begin{tabular}{|l|c|c|c|c|}
\hline & ORTHODOX & MUSLIM & CATHOLIC & PROTESTANT \\
\hline $\begin{array}{l}\text { To live with me in } \\
\text { the same } \\
\text { municipality }\end{array}$ & $24 \%$ & $93 \%$ & $18 \%$ & $10.5 \%$ \\
\hline $\begin{array}{l}\text { To live with me at } \\
\text { the same place }\end{array}$ & $19.2 \%$ & $91.3 \%$ & $16.3 \%$ & $7.6 \%$ \\
\hline $\begin{array}{l}\text { His children to } \\
\text { attend the same } \\
\text { school as my } \\
\text { children }\end{array}$ & $23.3 \%$ & $89 \%$ & $16.3 \%$ & $10.5 \%$ \\
\hline $\begin{array}{l}\text { To mingle with } \\
\text { him/her and be my } \\
\text { friend }\end{array}$ & $23.3 \%$ & $84.9 \%$ & $18.6 \%$ & $8.1 \%$ \\
\hline $\begin{array}{l}\text { My sister or } \\
\text { relative to get } \\
\text { married to him }\end{array}$ & $7 \%$ & $87.8 \%$ & $4.1 \%$ & $2.3 \%$ \\
\hline $\begin{array}{l}\text { To be mayor of my } \\
\text { municipality }\end{array}$ & $17.4 \%$ & $88.4 \%$ & $14 \%$ & $8.1 \%$ \\
\hline $\begin{array}{l}\text { To be director of } \\
\text { the organization } \\
\text { where I am } \\
\text { employed }\end{array}$ & $16.9 \%$ & $87.2 \%$ & $10.5 \%$ & $5.8 \%$ \\
\hline $\begin{array}{l}\text { To represent my } \\
\text { municipality in the } \\
\text { Parliament }\end{array}$ & $23.8 \%$ & $83.7 \%$ & $14 \%$ & $7.6 \%$ \\
\hline
\end{tabular}

\section{Extent of attachment to group belonging}

By using the so-called Likert scale to measure the responses, the next part presents the attitudes of the respondents that include components of the individual's attachment to a certain ethnic community or perception of certain ethnic attachments. The results from the research undertaken in 2015 are compared to the research undertaken on the same questions in 1995 and 2003 (Table 8).

According to N. Rot and N. Havelka, there are three types of national-ethnic attachment:

1. Exceptional national-ethnic attachment, characteristic of a pronounced attachment to one's own nation or ethnic group, it is of single relevance and importance, and responds to what is usually called ethnocentrism, nationalism or ethno-nationalism;

2. Distinct national-ethnic attachment, characteristic of pronounced attachment to one's nation, as well as acceptance that other loyalty 
exists, responds to national and ethnic idealization or patriotism; and

3. Multiple national-ethnic attachment, characteristic of the loyalty towards one's own nation and ethnic group, as well as towards the international cooperation and agreement, and known as internationalism (Tashevska, 2004).

A scale of nine responses/statements is used to determine the extent of attachment to one's ethnic or nationality group. The responses are analyzed on a fivefold scale, where 1 means strongly agree and 5 means fully disagree with the offered statement. The same scale of responses/statements is used for the three respective studies done in 1995, 2003 and 2015. Table 11 below presents the index based on the arithmetic mean of the responses. The following statements/responses were offered:

1. Every nation must have its own country;

2. Mixed marriages are doomed to fail;

3. One can feel safe in the surrounding only when the majority of the people there belong to the same ethnic community;

4. One can achieve cooperation among the ethnic communities, but not complete trust;

5. Everyone should feel as the destiny of the nation is his/her own destiny;

6. I feel the same belonging both to my nation and the humankind;

7. The feeling of national-ethnic belonging is one of the most beautiful feelings;

8. It is senseless to say that all nationalities - ethnic communities are equal, since it is obvious that some are more valuable;

9. The ones who belong to my nation should always show more appreciation for their nation.

\section{Table 8}

\begin{tabular}{|c|c|c|c|c|c|c|}
\hline & \multicolumn{6}{|c|}{ Ethnic origin } \\
\cline { 2 - 8 } & \multicolumn{3}{|c|}{ Macedonian } & \multicolumn{3}{c|}{ Albanian } \\
\cline { 2 - 8 } $\begin{array}{c}\text { Attitud } \\
\text { es }\end{array}$ & $\begin{array}{c}\text { Arithmet } \\
\text { ic mean }\end{array}$ & $\begin{array}{c}\text { Arithmet } \\
\text { ic mean }\end{array}$ & $\begin{array}{c}\text { Arithmet } \\
\text { ic mean }\end{array}$ & $\begin{array}{c}\text { Arithmet } \\
\text { ic mean }\end{array}$ & $\begin{array}{c}\text { Arithmet } \\
\text { ic mean }\end{array}$ & $\begin{array}{c}\text { Arithmet } \\
\text { ic mean }\end{array}$ \\
\hline 1. & 2.61 & 2.54 & 2.42 & 1.96 & 1.12 & 1.69 \\
\hline 2. & 3.39 & 3.02 & 3.21 & 2.10 & 2.00 & 2.34 \\
\hline 3. & 3.00 & 1.87 & 2.78 & 2.29 & 1.87 & 1.99 \\
\hline 4. & 2.32 & 2.00 & 2.57 & 2.13 & 1.94 & 2.08 \\
\hline 5. & 2.35 & 2.20 & 2.79 & 2.03 & 1.79 & 2.04 \\
\hline 6. & 2.07 & 1.76 & 1.94 & 1.93 & 1.46 & 2.13 \\
\hline 7. & 2.59 & 3.00 & 2.34 & 1.99 & 1.85 & 1.65 \\
\hline 8. & 3.06 & 3.24 & 2.79 & 2.42 & 2.06 & 2.08 \\
\hline 9. & 2.67 & 2.53 & 2.40 & 2.11 & 1.94 & 1.82 \\
\hline
\end{tabular}


The presented data in Table 8 indicate certain difference in the perception of Macedonians and Albanians in Republic of Macedonia. Macedonians strongly disagree with the statement "Mixed marriages are doomed to fail", while one can notice a minimal discrepancy with the post-conflict period in terms of hesitation. However, in the post conflict period from 1995 and in 2015, the index is on the increase, which indicates a shift from hesitation to disagreement. Although the index is lower, the same trend can be noticed among the Albanian respondents. Hence, if disagreement existed in the postconflict period in 2003, in the pre-conflict period and during the research of 2015 , there is shift in the attitudes from agreement to hesitations. This question shows that despite the clear social segregation of the two biggest ethnic communities, there is a shift towards tolerance for diversity, even for the most sensitive social segment such as mixed marriages, which, in fact, enhances the possibilities for inter-ethnic tolerance.

The lowest index concerning the Macedonians is noticed about the sixth question, which is a combination of national centrism and universalism, which, although seemingly impossible to combine at first sight, is possible to connect with the level of abstraction, where the nation is a specific notion, while humankind is more of an abstract category.

Clear fluctuation in the answers of the Macedonians may be noticed regarding questions 7 and 8, which imply agreement with the superiority of one's own group and emotional attitude towards one's nation. These feelings are on the decline in the post-conflict period, as in the research from 2003, while the index from the 2015 research is even lower than the index in the pre-conflict period. The shift from hesitation to agreement indicates the strengthening of the national centrism or ethno-centrism of the majority group in the country.

In addition, regarding questions 1 and 9 , there is a clear tendency among Macedonian respondents for a shift from hesitation to agreement. Again, this refers to the previous idea that, although mild, there is a persistent tendency to enhance the Macedonian national feeling, even to the extent that one would feel safer within one's own community. As opposed to this, Macedonians show the strongest feeling of identifying their destiny with the nation in 2003, while this attitude now shifts from agreement to hesitation (Chart 6). 


\section{Chart 6}

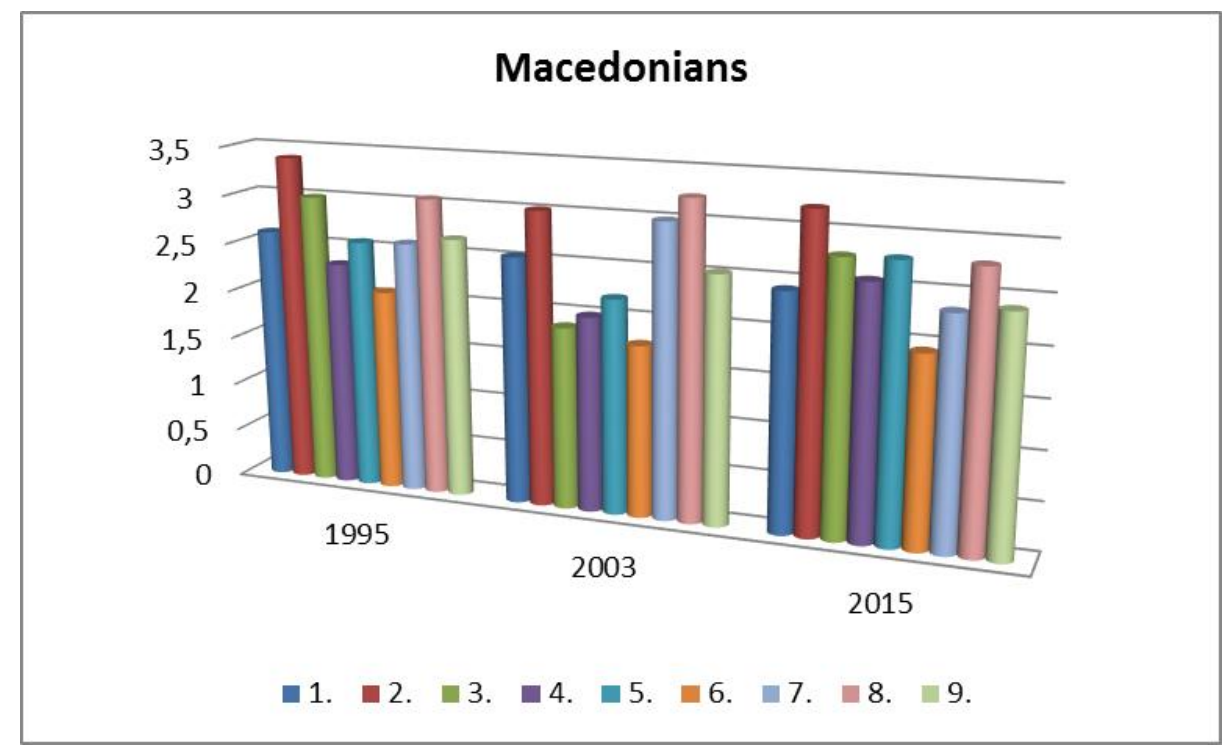

In comparison with the responses given by the Macedonian respondents, the attitudes of the Albanian respondents, as shown on Table 8, indicate a more distinct ethno-centrism of the group, which most often ranges between agreement and full agreement. The tendencies shown among the Albanians overlap with the tendencies among the Macedonians. Thus, in question 6 there is a mild shift towards universalism, that is, a mild shift from the feeling of agreement to hesitation. On the questions 7 and 8, which imply having agreement about the superiority of one's own group and emotional attitude towards one's own nation, there is a shift towards agreement to full agreement. The greatest shift among the Albanians is with regard to the second question, from agreement to hesitation, which, in fact, indicates the gradual evolution of attitudes towards acceptance of diversity, reflected on the mild tendency to accept mixed marriages. Although the desire to more appreciate one's own nation is on the increase, as represented by the answers given on the ninth question, which shows continuous tendency for increased agreement, among the Albanian respondents there is increased index for the first question, which is clearly on the increase, and, in particular, in comparison with the post-conflict period shifts from full agreement to agreement (Chart 7). 


\section{Chart 7}

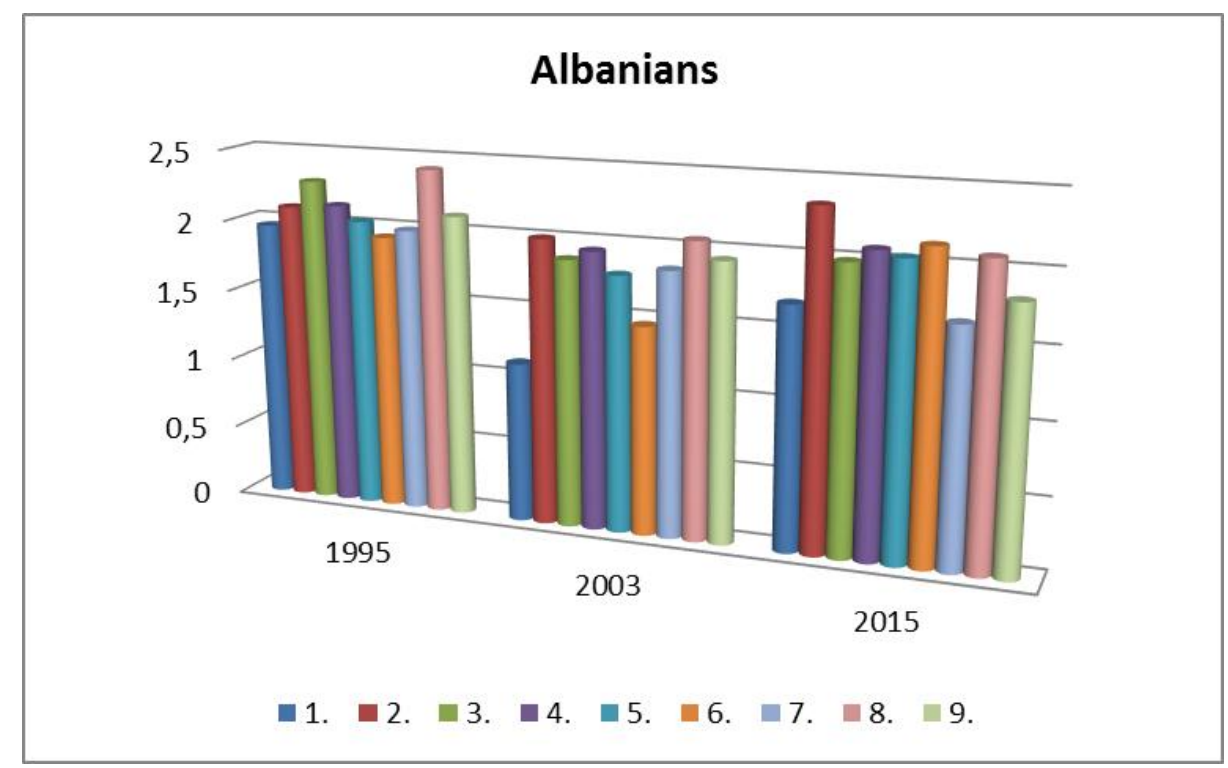

The analysis of attitudes is further supported by the response of the respondents on questions related to the identification of the groups with different levels of attachment, from attachment to the local community to the universalism, as well as attachment to the global environment. In this question, the groups to which the respondents belong were ordered. By choosing one of the options (very important, average importance, little important, unimportant), respondents decide how important to them to belong to each of these groups. The index derives from the arithmetic mean of attitudes, where 1 is very important and 4 is unimportant. The following groups were offered: town/village, region, nationality, religion, occupation, state, Balkan, Europe and world/humankind.

The results presented on Table 9 and Chart 8 show that most important both for the Macedonians and Albanians is the feeling of belonging to the nationality, which among the Macedonians shows a mild shift from average importance to very important, while it inclines more towards very important among the Albanians. This is an indication of the strong ethno-centrism in the Macedonian society. For the Albanian respondents, religious affiliation is equally important to the national-ethnic belonging, while in the attitudes of the Macedonian respondents it is of average importance and there is a mild shift towards little importance. The results showing the importance that Albanian respondents attach to the local community (town/village) and especially to the occupation is somewhat surprising. This might be explained by the strong traditionalism in this community, and their traditionally 
insufficient incorporation in the state sector or larger companies, with rather attachment to the family business as basic tool for economic organization in this community. For both of the communities, least important are the feelings of belonging to the state and the wider region of the Balkan. The lower importance attached to the state seems to be more problematic, and ranges from average importance to little importance, especially in the Macedonian ethnic community, which also experiences the state as its own national state (Table 9 and Chart 8). ${ }^{16}$

\section{Table 9}

\begin{tabular}{|l|c|c|}
\hline \multirow{2}{*}{\multicolumn{1}{|c|}{ Attitudes }} & \multicolumn{2}{|c|}{ Ethnic origin } \\
\cline { 2 - 3 } & Macedonian & Albanian \\
\cline { 2 - 3 } \multicolumn{1}{|c|}{} & $\mathbf{2 0 1 5}$ & $\mathbf{2 0 1 5}$ \\
\hline 1. town/village & Arithmetic mean & Arithmetic mean \\
\hline 2. region & 2.06 & 1.70 \\
\hline 3. nationality & 2.20 & 1.80 \\
\hline 4. religion & 1.98 & 1.41 \\
\hline 5. occupation & 2.14 & 1.40 \\
\hline 6. state & 2.24 & 1.59 \\
\hline 7. Balkan & 2.25 & 2.15 \\
\hline 8. Europe & 2.30 & 2.17 \\
\hline 9. world/humankind & 2.11 & 2.04 \\
\hline
\end{tabular}

${ }^{16}$ By results of the research published by Hristova and Cekik, the most important for Macedonians and Albanians are the family and friends. Height in importance by Albanian surveyed is the religion and low is the state or statehood. Both for Macedonian and Albanian less important are the political parties (Hristova and Cekik, 2014). 


\section{Chart 8}

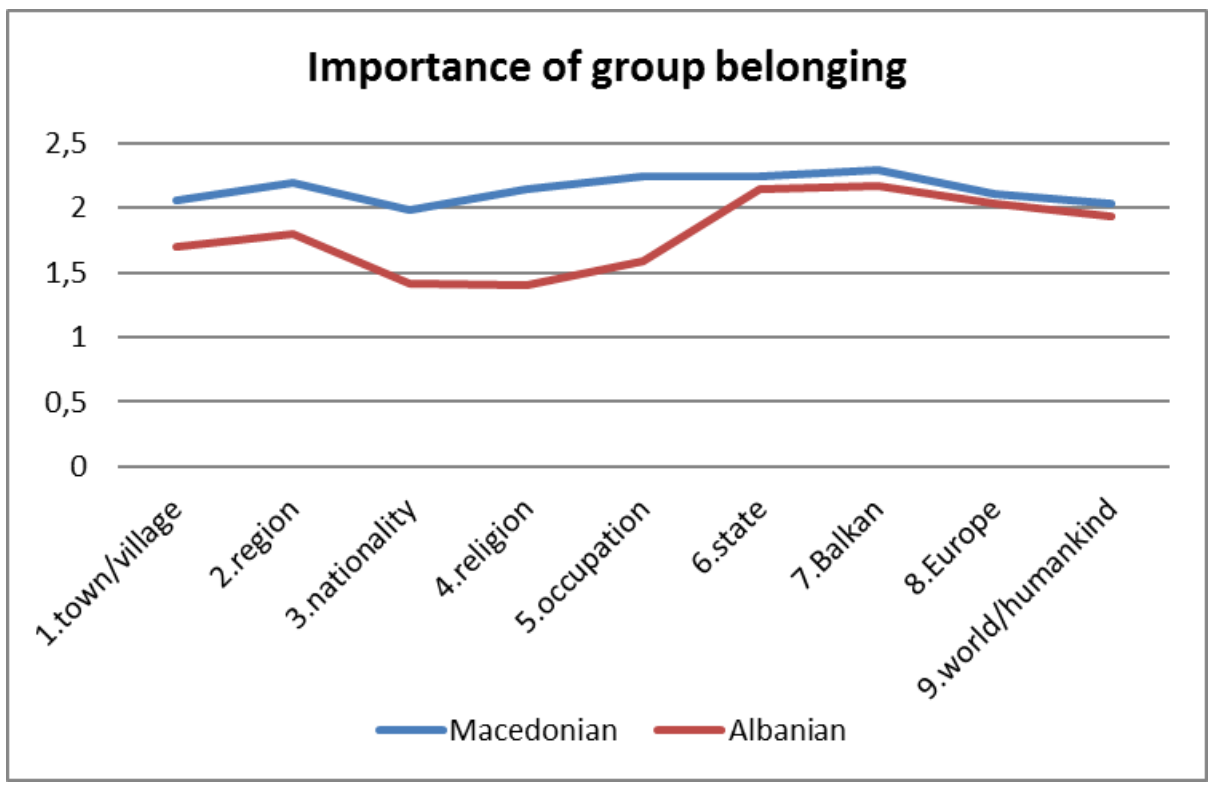

\section{Conclusion}

There is a distinct ethnic distance in the country from the aspect of stereotypes that ethnic communities construe about each other. Negative stereotypes are mutually construed in the relations between the Macedonian and Albanian ethnic community, but unlike the pre-conflict and post-conflict period, there is a mild shift towards creation of preconditions to gradually tackle the negative stereotyping. Both of the largest ethnic communities construe stereotypes about the Turkish ethnic community, which are quite positive, and about the Roma community, which are quite negative.

Prejudices of both the Albanian and Macedonian ethnic group have distinct paternalistic characteristics and competitive component. The first one refers to a marked negative drive with regard to the values and cultural level of the Other, while the second one refers to the competitive relations among the ethnic groups, which is prompted by the feeling of being threatened and having limited access to social resources.

Ethnic distance in the country is still strongly accented, in relation to the religious denomination and general cultural characteristics. Nevertheless, there is clearly marked tendency toward reducing the ethnic distance, which is a fact of encouragement, and can be noticed in mutual relations both in the Macedonian and Albanian community. Although closeness within these two communities is still strongly expressed, the only tendency for increasing the 
ethnic distance refers to the attitude of the Macedonian to the Serbian ethnic community.

Interpersonal distance in the country is most apparent in the relations that the two biggest ethnic communities have towards the Roma ethnic community. Interpersonal distance in mutual relations between the Macedonian and Albanian ethnic community is most apparent in matters related to traditional institutions, such as marriage; however, it is significantly lower considering the perception of inter-ethnic interaction based on making friendships. A surprising fact is that despite the segregation within the educational system, the educational distance is not so strongly marked. With regard to the religious distance, one can notice greater distancing by the members of the Islamic community from other religions, in comparison with the attitudes that members of the Christian-Orthodox community have towards the others.

Ethnocentrism and one's identification with the religion are strongly marked. Despite the fact that this prevails in the Albanian ethnic community, one can notice a tendency to enhance the importance attached to the nation as primary identification with the group in the Macedonian ethnic community.

Having no strong feelings for identification of oneself with the state, which exists both in the Macedonian and Albanian ethnic community, may contribute to a decline in the feeling of loyalty to the state in the future. From the aspect of this type of loyalty, there is inversely proportional tendency that follows the strengthening of the national feeling and tendency for enhancing the ethnification in the Macedonian societal context.

The religious background for the Albanian respondents is equally important as the ethnic origin, while there is a shift towards attaching little importance among the Macedonian respondents. 


\section{Bibliography}

Atanasov Petar and Bojana Naumovska (2016) Mladite pomegu kolektivnite identiteti I individualizacijata. In, Cvetanova, Atanasov and oth. Identitetite na studentskata populacija vo Republika Makedonija. Skopje: Institut za socioloski I politicko-pravni istrazuvanja, pp. 49-71.

Burdiak Vira (2010) Influence of Ethnic Stereotypes on the Development of Political Relations in the Balkan Countries. In, Codrul Cosminului, XVI, No. 2, pp. 147-157.

Bogardus, Emory S. (1925) Measuring social distance. Journal of Applied Sociology 9: 299-308.

Caselli, Francesco and Coleman, Wilbur John (2013) On the theory of ethnic conflict. Journal of the European Economic Association, 11 (S1). pp. 161-192. ISSN 15424766.

Demjaha Agon (2017) The State of Inter-Ethnic Relations in Macedonia after 16 years of the Ohrid Agreement. In, SEEU Review Volume 2 Issue 2, pp. 8-31. DOI: 10.1515/seeur-2017-0016.

Desmet Klaus, Ignacio Ortuco-Orthn, and Romain Wacziarg (2017) Culture, Ethnicity, and Diversity. In, American Economic Review, 107(9): 24792513, https://doi.org/10.1257/aer.20150243

Eagly, A. H., \& Diekman, A. B. (2005) What is the problem? Prejudice as an attitude-in-context. In J. F. Dovidio, P. Glick, \& L. A. Rudman (Eds), On the Nature of Prejudice: Fifty Years After Allport (pp. 19-35). Malden, MA: Blackwell.

Ebner, Christian; Helbling, Marc (2016) Social distance and wage inequalities for immigrants in Switzerland, Work, Employment and Society, ISSN 1469-8722, Sage, Thousand Oaks, CA, Vol. 30, Iss. 3, pp. 436-454, http://dx.doi.org/10.1177/0950017015594096

Gürcan Ültanır, Emel Ültanır and Ayșe Irkörücü (2016) A Comparison of Stereotypes of German and Turkish Students towards Balkans. In, International Journal of Instruction, Vol.9, No.1, pp. 93-106.

Hammel, Mason \& Stevanović (2010) Ethnic diversity, segregation, and the collapse of Yugoslavia. In, Demographic Research, Volume 22, Article 35, pp. 1098-1142.

Hewstone, M. (1990). The "ultimate attribution error"? A review of the literature on intergroup attributions. European Journal of Social Psychology, 20, 311-335. 
Horowitz, Donald. (1985) Ethnic Groups in Conflict. Berkeley: University of California Press.

Hristova, Lidija and Aneta Cekik (2014) Hierarhija na Identitetskite crti. In, Hristova and other., Percepciite na identitetite na studentskata populacija vo Republika Makedonija. Skopje: Institut za socioloski I politicko pravni istrazuvanja, pp. 43-61.

Joshi Ankur and others (2015) Likert Scale: Explored and Explained. In, Current Journal of Applied Science and Technology 7(4), pp. 396-403.

Karakayali Nedim (2009) Social Distance and Affective Orientations. In, Sociological Forum, Vol. 24, No. 3, pp. 538-562. DOI: 10.1111/j.15737861.2009.01119.x.

Lippmann, W. (1922) Public Opinion. New York: Harcourt, Brace.

Malenica Krunoslav, Vlaho Kova and Goran Kardum (2019) Impact of Religious Self Identification and Church Attendance on Social Distance toward Muslims. In, Religions, 10, 276; doi:10.3390/rel10040276.

Martinoska, Ana (2005) Ethnic Stereotypes in the Macedonian Folklore and their Reflection in the Macedonian Contemporary Literature. In, Neohelicon XXXII (2005) 1, pp. 71-79. Budapest: Akadémiai Kiadó, Springer.

Pace, Enzo. (2009) Zašto religije ulaze u rat? Zagreb: Golden marketingTehnicka knjiga.

Park, E. Robert (1924): The Concept of Social Distance. Journal of Applied Sociology, 8 (5): 339-344.

Raskovic Matevž and Davor Vuckovski (2016) National Stereotypes and Social Distance toward Slovenians among Former Yugoslav Countries: 25 Years Later. In, Teorija i praksa, let. 53.5, pp. 1079-1094.

Remenski, Frosina (2004) Albanians and Macedonians: The ethnic interaction in Republic of Macedonia, Before and After the Conflict from 2001. Skopje: Institute of sociology, Faculty of philosophy, University "Ss Ciril and Methodious"-Skopje.

Rinehart, W. James (1963): The Meaning of Stereotypes. In, Theory into Practice 2 (3): 136-143.

Semyonov Moshe and Anya Glikman (2009) Ethnic Residential Segregation, Social Contacts, and Anti-Minority Attitudes in European Societies. In, European Sociological Review, Vol. 25 N0 6, pp 693-708. DOI:10.1093/esr/jen075, available online at www.esr.oxfordjournals.org. 
Tasheva, Marija (1997) Ethnic groups in Republic of Macedonia (current situation). Skopje: Faculty of philosophy-Skopje.

Várnai, Zsanett (2009) Common National Stereotypes and their Impact on Hungary’s Trade Relations. Budapest: Budapesti Gazdasági Föiskola.

Verberk Genevieave, Peer Scheepers and Albert Felling (2002) Attitudes and behavioural intentions towards ethnic minorities: an empirical test of several theoretical explanations for the Dutch case. In, Journal of Ethnic and Migration Studies Vol. 28, No. 2: 197-219.

Wark Colin \& John F. Galliher (2007) Emory Bogardus and the Origins of the Social Distance Scale. In, American Sociologist, 38, pp. 383-395: Springer Science, Business Media, LLC.

Zupancic Rok and Jana Arbeiter (2017) Primitive, cruel and blood-thirsty savages': Stereotypes in and about the Western Balkans. In, Teorija I praksa, let. 53, 5, pp. 1051-1063. 